\title{
INCREASING STUDENT'S SOCIAL SKILL THROUGH PLAYING METHOD
}

\author{
RADJIMAN ISMAIL \\ Institut Agama Islam Negeri Ternate \\ Jl. Lumba-Lumba Kel. Dufa-Dufa Kota Ternate, Maluku Utara \\ Tlp. (0921) 3121426 Fax 3123773 email: radjiman_ismail@yahoo.com
}

\begin{abstract}
The aim of this research is to increase students' social skill to children in the group $B$ through playing method. The methodology of it was consisting three cycles. The research sample is 32 students of PAUD An-Nisa Institut Agama Islam Negeri Ternate. Technique was used of this research by using questioners. The result shows that; (1) pretest was doing before cycle I consist of 30\% have social skill as good, 20\% have social skill is very good, 50\% have social skill is poor; (2) the final test for cycle I consist of 50\% have social skill as very good; $20 \%$ have social skill good, $30 \%$ have social skill is poor; (3) the final test for cycle II consist of 65\% have social skill as good, $20 \%$ is almost good and $15 \%$ is poor;(4) the final test for cycle III consist of $80 \%$ have social skill as good, $15 \%$ is almost good, and 5\% is poor. Based on the result, the researcher concludes that playing method is effective to increase students' social skill.
\end{abstract}

Key word: social skill, playing method

\begin{abstract}
Abstrak : Penelitian ini bertujuan untuk meningkatkan keterampilan sosial pada siswa pendidikan anak usia dini kelas B melalui metode bermain kelompok. Penelitian menggunakan metode penelitian tindakan sebanyak tiga siklus. Sampel penelitian berjumlah 32 siswa pendidikan anak usia dini An Nisa Institut Agama Islam Negeri Ternate. Berdasarkan hasil penelitian diperoleh data sebagai berikut; (1) pre test sebelum siklus pertama sebanyak 30 persen sudah memiliki keterampilan sosial secara baik, 20 persen cukup baik, dan 50 persen kurang baik; (2) tes akhir siklus pertama sebanyak 50 persen siswa memiliki keterampilan sosial sangat baik, 20 persen cukup dan 30 persen kurang baik; (3) tes akhir siklus kedua menunjukkan 65 Persen siswa sudah memiliki keterampilan sosial baik, 20 persen cukup baik dan 15 persen kurang baik; (3) tes akhir siklus tiga menunjukkan 80 persen memiliki keterampilan sosial baik, 15 persen cukup baik, dan 5 persen kurang baik. Berdasarkan hasil penelitian dapat disimpulkan bahwa metode bermain kelompok efektif digunakan untuk meningkatkan keterampilan sosial pada anak.
\end{abstract}

Kata kunci: siswa anak usia dini, keterampilan sosial, metode bermain kelompok. 
Guru pada anak usia dini perlu menanamkan keterampilan sosial. Hal ini penting dilakukan karena ada fenomena pembelajaran di ruang-ruang kelas sering dijumpai anak-anak asyik dengan aktivitas dengan dirinya sendiri, seperti mewarnai, melipat, menggunting, menempel. Kondisi pembelajaran dengan aktivitas seperti ini kurang memberi ruang kepada anak melakukan interaksi satu dengan lainnya. Jika hal ini terus dilakukan dapat menyebabkan anak kurang memahami karakteristik teman di kelas. Rasa simpati dan empati perlahan tapi pasti kemudian hilang dari anak. Aktivitas di kelas sebaiknya melibatkan interaksi secara berkesinambungan sehingga dapat menumbuhkan sikap simpati, empati, saling menghargai, bertanggung jawab serta toleran. Menumbuhkan dan mengembangkan sikap sikap seperti ini dapat dilakukan pada setiap pembelajaran sehingga pada akhirnya menjadi pembiasaan pada diri anak.

Guru dalam melaksanakan pembelajaran secara menyeluruh tersebut dalam rangka membentuk, mengembangkan, serta menumbuhkan tidak hanya kecerdasan intelektual pada anak tetapi juga kecerdasan interpersonal, intrapersonal serta emosional. Keempat kecerdasan tersebut diharapkan dapat menumbuhkan keterampilan sosial. Jika sejak dini telah ditanamkan keempat jenis kecerdasan diharapkan anak memiliki keterampilan sosial yang baik sehingga dapat bergaul secara baik pula. Pembelajaran keterampilan sosial tidak dapat dilakukan dengan jangka pendek tetapi secara terus menerus dan berkesinambungan. Dengan demikian setiap program pembelajaran memuat aspek-aspek keterampilan sosial sesuai dengan tujuan dan harapan yang hendak dicapai.

Pembelajaran keterampilan sosial dapat terlaksana dengan baik serta sesuai dengan tujuan jika dilakukan dalam bentuk kelompok. Anak di dalam kelompok belajar untuk bertanggung jawab, disiplin, menghargai orang lain, toleransi, tenggang rasa, serta mau menerima kelebihan dan kekurangan orang lain. 
Untuk dapat menanamkan keterampilan sosial ini diperlukan metode yang selalu berinteraksi antara satu anak dengan anak lainnya. Bermain kelompok merupakan salah satu metode yang dapat dipilih oleh guru.

Guru pada pada kenyataannya dalam pembelajaran pada masih sedikit menggunakan metode bermain dan permainan yang terstruktur. Metode atau permainan terstruktur dalam arti langkahlangkah yang digunakan jelas untuk mencapai tujuan pembelajaran. Anak dan guru tidak hanya sekedar bermain atau melakukan permaian tetapi setiap bermain dan permainan tersebut dilakukan untuk mencapai tujuan pembelajaran. Dengan kata lain, bermain atau permainan dalam pembelajaran dilakukan by design, sehingga langkah-langkah yang dilakukan dapat evaluasi setiap saat.

\section{Kajian Teoritis}

Bermain merupakan aktivitas yang sering dilakukan oleh anakanak. Bermain tidak hanya melibatkan fisik tetapi juga emosi dan pikiran. Anak-anak yang bermain dengan boneka misalnya, sering memerankan dirinya sendiri sebagai orang dewasa. Pada permainan dengan menggunakan boneka ini tidak hanya melibatkan kemampuan fisik tetapi juga pikiran dan emosi. Pada fisik anak melakukan berbagai macam gerakan, pada pikiran anak membayangkan dirinya menjadi orang tua, dan emosi berusaha melakukan empati dan simpati terhadap boneka yang mungkin dianggap sebagai adik atau temannya.

Pakar bidang psikologi perkembangan sangat menekankan pentingnya bermain pada anak usia dini. Bermain pada masa usia dini memiliki manfaat yang sangat besar pada saat usia remaja, dewasa, bahkan pada saat usia tua. Monk (2002:132) mengutip pernyataan Groos, Hall, Spencer, dan Schaler bahwa permainan harus dipandang sebagai latihan fungsi-fungsi yang sangat penting dalam kehidupan dewasa nanti. Bermain selain memiliki manfaat pada pertumbuhan fisik tetapi juga melibatkan perkembangan otak dan sikap. Kehidupan masa dewasa dapat 
dilihat pada masa kanak-kanak, apakah memiliki waktu yang cukup untuk bermain atau tidak.

Bermain dan permainan dapat pula meningkatkan kemampuan dalam berpikir kreatif. Di dalam bermain dapat mengemukan ide yang dapat dijadikan sebagai saran untuk mengembangkan kemampuan berpikir kreatif. Anak dapat mengembangkan pemikiran kreatif sesuai dengan masalah yang dihadapi. Bermain memiliki tingkatan dalam mengolah keterampilan, baik keterampilan berpikir maupun keterampilan sosial. Kedua jenis keterampilan ini seperti dua sisi mata uang. Semakin rumit jenis permainan maka akan semakin terampil berpikir dan terampil dalam bersikap.

Padmonodewo

(2003:102)

mengutip pernyataan Schwartzman bahwa bermain bukan bekerja, bermain adalah pura-pura, bermain bukan sesuatu yang sungguhsungguh, bermain bukan suatu kegiatan yang produktif. Namun demikian di dalam bermain anak dapat mengembangkan imajinasi serta melakukan interaksi dengan teman sebaya. Di dalam bermain anak juga tidak dituntut untuk menghasilkan suatu produk tetapi lebih menekankan pada proses bagaimana produk itu dihasilkan. Anak-anak yang bermain dengan lego dan membangun sebuah gedung atau jembatan merupakan sebuah produk tetapi produk itu kemudian dapat dibongkar kembali. Pemikiran kreatif dan proses membangun itulah lebih penting dari produk itu sendiri.

Slavin (2008:99) seperti mengutip pernyataan Pattern bahwa ada empat jenis permainan yang mencerminkan tingkat interaksi sosial dan keterampilan yang meningkat. Keempat jenis permainan tersebut yaitu permainan soliter, permainan paralel, permainan asosiatif, dan permainan kooperatif. Anak melalui berbagai permainan ini dapat mengembangkan semua imajinasi. Anak juga dapat melakukan kerjasama dengan teman di dalam permainan. Pada permainan kooperatif misalnya, di dalam bermain ini anak dapat melakukan interaksi satu dengan lainnya. Interaksi daapt dilakukan melalui bahasa verbal maupun nonverbal. 
Melalui kedua bahasa ini anak belajar tentang keterampilan sosial.

$$
\text { Kak Seto }
$$

menyatakan bermain adalah sesuatu yang menyenangkan dan memiliki nilai positif bagi anak dan tidak memiliki tujuan ekstrinsik namun motivasinya lebih bersifat intrinsik. Anak-anak bermain pada prinsipnya menyalurkan rasa keingintahuan serta melepaskan semua energi yang ada. Di dalam bermain soliter maupun kelompok tetap membutuhkan keterampilan sosial di samping keterampilan berpikir.

Monk (2002:122) seperti mengutip pendapat Gerris bahwa perkembangan sosial dapat dibagi menjadi tiga bagian yaitu; (1) kognisi sosial; (2) kecakapan dalam bergaul dengan orang lain; dan (3) nilai-nilai sosial. Jadi kecakapan dalam bergaul yaitu suatu keterampilan dalam melakukan interaksi sosial merupakan bagian tak terpisahkan dari perkembangan anak. Di dalam perkembangan sosial tersebut juga ada perkembangan kognisi sosial serta nilai-nilai sosial. Pembelajaran keterampilan sosial penting dilakukan sejak dini karena hal tersebut menjadi bagian tak terpisahkan dalam rentang kehidupan manusia.

Erikson (2010:291-318) membagi perkembangan sosial selama rentang kehidupan menjadi delapan tahap melampaui siklus kehidupan. Masing-masing tahap terdiri dari tugas perkembangan yang khas dan mengedepankan individu dengan suatu krisis yang harus dihadapi. Bagi Erikson, krisis ini bukanlah suatu bencana, tetapi suatu titik balik peningkatan kerentanan dan peningkatan potensi. Semakin berhasil individu mengatasi krisis, akan semakin sehat perkembangan mereka. Untuk dapat mencapai perkembangan sosial yang memadai diperlukan intervensi dalam pembelajaran. Anak sejak dini diajarkan untuk senantiasa dapat berkolaborasi dengan teman sebaya sehingga mampu memahami rasa empati dan simpati.

Anak usia dini dengan perkembangan sosial yang baik salah satunya dapat dicerminkan melalui kecerdasan yang dimiliki. Gardner (dalam Amstrong, 2002:2) 
menyebutnya sebagai kecerdasan interpersonal dan intrapersonal

Kecerdasan intrapersonal

yaitu kemampuan seseorang untuk memahami dan mampu bekerjasama dengan orang lain, berempati dengan orang lain, serta mampu mempengaruhi orang lain. Orangorang yang memiliki kecerdasan ini antara lain; PR, konselor/psikolog, dan semua profesi yang berhubungan dengan orang lain. Kecerdasan interpersonal berhubungan dengan kemampuan seseorang untuk mampu mengenali dirinya sendiri, baik kelemahan, kekuatan, serta mampu membawa diri dalam pergaulan publik. Kecerdasan ini biasanya dimiliki oleh para konselor, PR, serta profesi yang bertugas memberi motivasi dan terapi.

Anak dengan kecerdasan interpersonal ditandai ciri-ciri sebagai berikut; (1) Menunjukkan sikap mandiri atau kemauan keras; (2) Memahami dengan baik kelebihan dan kekurangan diri; (3) Tidak mengalami masalah jika ditinggalkan bermain atau belajar sendirian; (4) Memiliki gaya hidup dan gaya belajar dengan irama tersendiri; (5) Memiliki minat dan hobi yang jarang ia bicarakan; (6) Memiliki perencanaan diri yang baik; (7) Lebih memilih bekerja sendiri daripada bekerja dengan orang lain; (8) Dapat mengekspresikan perasaan secara kuat; (8) Mampu belajar dari kegagalan dan keberhasilan yang pernah dialami; (9) Memiliki rasa penghargaan terhadap diri sendiri yang baik.

Keterampilan sosial selain dicirikan melalui kecerdasan interpersonal dan intrapersonal dapat pula ditunjukkan melalui kemampuan mengelola emosi. Emosi dapat berpengaruh dan mengganggu aktivitas mental karena kegiatan mental seperti konsentrasi, daya ingat, penalaran sangat mudah dipengaruhi oleh emosi yang kuat. Anak-anak akan menghasilkan prestasi di bawah kemampuan intelektual mereka bila emosi mereka terganggu. Misalnya, anak sulit berkonsentrasi pada suatu aktivitas bila kondisi emosi anak tidak stabil atau terganggu.

Sternberg $(2004: 474)$ mengemukakan bahwa kecerdasan 
emosional adalah kemampuan mengenali emosi diri, yang merupakan kemampuan seseorang dalam mengenali perasaannya sendiri sewaktu perasaan atau emosi itu muncul, dan ia mampu mengenali emosinya sendiri apabila ia memiliki kepekaan yang tinggi atas perasaan mereka yang sesungguhnya dan kemudian mengambil keputusankeputusan secara mantap. Kemampuan mengelola emosi merupakan kemampuan seseorang untuk mengendalikan perasaannya sendiri sehingga tidak meledak dan akhirnya dapat mempengaruhi perilakunya secara wajar. Misalnya seseorang yang sedang marah maka kemarahan itu tetap dapat dikendalikan secara baik tanpa harus menimbulkan akibat yang akhirnya disesali di kemudian hari.

\section{Goleman}

(2000:21)

menyatakan bahwa anak yang mempunyai kecerdasan emosi memiliki toleransistik seperti mampu memotivasi diri sendiri, mampu bertahan menghadapi frustrasi, mampu mengendalikan dorongan hati, memiliki empati yang tinggi. Selain itu, juga dicirikan yakni lebih cakap untuk menjalankan jaringan informalnya atau nonverbal, luwes untuk menemukan cara alternatif agar sasaran tetap tercapai atau untuk mengubah sasaran jika pada awalnya sulit dijangkau, memiliki kepercayaan yang tinggi meski sedang menghadapi kondisi yang sulit, mempunyai keberanian untuk memecahkan tugas yang berat dan merasa cukup banyak akal untuk menemukan cara dalam meraih tujuan.

Pembelajaran keterampilan sosial pada anak usia dini yang paling memiliki pengaruh adalah melakukan imitasi. Anak secara sadar akan mencontoh baik teman sejawat maupun orang dewasa di sekelilingnya terhadap perilaku yang dilihatnya. Wirawan (2001:21) seperti mengutip pendapat Miller dan Dollard yaitu dalam laporan hasil percobaannya mengatakan bahwa peniruan (imitation) di antara manusia tidak disebabkan oleh unsur insting atau program biologis. Penelitian kedua orang tersebut mengindikasikan bahwa kita belajar (learn) meniru perilaku orang lain. Artinya peniruan tersebut merupakan 
hasil dari satu proses belajar, bukan bisa begitu saja karena insting. Proses belajar tersebut oleh Miller dan Dollard dinamakan "social learning " - "pembelajaran sosial". Perilaku peniruan (imitative behavior) kita terjadi karena kita merasa telah memperoleh imbalan ketika kita meniru perilaku orang lain, dan memperoleh hukuman ketika kita tidak menirunya.

Boeree (2002:215) mengutip pendapat James dan Dewey yaitu menekankan pada penjelasan kebiasaan individual, tetapi mereka juga mencatat bahwa kebiasaan individu mencerminkan kebiasaan kelompok - yaitu adat-istiadat masyarakat - atau struktur sosial. Struktur sosial terdiri atas jalinan interaksi antar manusia dengan cara yang relatif stabil. Kita mewarisi struktur sosial dalam satu pola perilaku yang diturunkan oleh satu generasi ke generasi berikutnya, melalui proses sosialisasi. Pembelajaran melalui bermain merupakan salah satu proses sosialisasi mengembangkan keterampilan sosial pada anak usia dini. Untuk itu perlu dilakukan pengkondisian pembelajaran. Pengkondisian ini bertujuan agar perilaku sosial pada anak sesuai dengan harapan dan tujuan pembelajaran keterampilan sosial itu sendiri.

Pengkondisian pembelajaran melalui metode bermain pada anak usia dini memberi ruang terjadinya interaksi antara siswa satu dengan siswa lainnya. Keterampilan melakukan interaksi penting diberikan sejak dini karena dapat melatih anak untuk dapat menggunakan kecerdasan emosinya secara baik dan tepat. Kecerdasan emosi merupakan bagian penting dari keterampilan sosial karena kemampuan menempatkan diri, memahami orang lain, menerima dan mengakui kelebihan orang lain, serta mampu menempatkan diri merupakan bagian dari keterampilan sosial. Keberhasilan atau kesuksesan dalam kehidupan tidak hanya ditentukan oleh kemampuan intelektual semata tetapi juga bagaimana kemampuan mengelola emosinya. Goleman (2000:20) menyatakan bahwa keterampilan emosi disebut sebagai kecerdasan 
emosi (emotional intelligence) atau emotional quotient (EQ). Kontribusi kesuksesan pengembangan diri dari faktor intelligence quotient atau IQ hanya sekitar 20 persen dan sisanya sekitar 80 persen ditentukan kecerdasan emosional.

Guru melalui pengkondisian pembelajaran dapat menyiapkan anak usia dini meraih sukses masa depan. Kesuksesan tidak hanya diperoleh dengan meningkatkan kemampuan IQ tetapi harus diimbangi dengan kemampuan EQ. Kedua kecerdasan ini dilakukan seiring dan sejalan. Dengan kata lain, pembelajaran tidak menitikberatkan pada kemampuan intelektual semata tetapi juga harus mengembangkan kemampuan emosinya. Jika pembelajaran dilakukan secara seimbang bukan tidak mungkin anak memiliki keterampilan sosial lebih baik dan berguna untuk meraih kesuksesan dalam kehidupannya kelak.

Berdasarkan latar belakang
permasalahan dan kajian teoritis
yang digunakan maka tujuan
penelitian dapat dirumuskan sebagai
berikut; (1) Meningkatkan

keterampilan sosial melalui metode bermain kelompok; (2) Mengukur efektivitas metode bermain kelompok untuk meningkatkan keterampilan sosial.

\section{METODOLOGI PENELITIAN}

Penelitian menggunakan riset tindakan yang dikembamgkan oleh Kemmis dan Taggart (dalam Lewin, 1990:41-45). Ada empat langkah dalam penelitian tindakan ini yaitu; (1) Perencanaan; (2) Pelaksanaan; (3) Observasi; dan (4) Refleksi. Sampel penelitian siswa pendidikan anak usia dini kelas B An-Nisa, Institut Agama Islam Negeri Ternate, Maluku Utara. Pelaksanaan penelitian dilakukan sebanyak tiga siklus dalam satu tema.

Teknik pengambilan data keterampilan sosial melalui pengamatan. Aspek keterampilan sosial yang diamati antara lain; (1) Kerjasama; (2) Mampu berkomunikasi verbal dan nonverbal; (3) Bertanggung jawab; (4) Empati dan (5) Simpati. Indikator penilaian untuk masing-masing aspek dengan menggunakan kategori baik (B) jika siswa menampakkan perilaku sering 
berdasarkan aspek keterampilan sosial, cukup (C) jika siswa menampakkan perilaku kadangkadang berdasarkan aspek keterampilan sosial, dan kurang $(\mathrm{K})$ jika siswa tidak menampakkan perilaku berdasarkan aspek keterampilan sosial. Teknik analisis data dengan menggunakan deskriptif.

\section{HASIL DAN PEMBAHASAN}

Pada siklus pertama siswa diajak bermain "Menyeberangi Sungai Dengan Perahu". Permainan ini setiap kelompok beranggotakan lima sampai enam orang. Perahu yang digunakan dengan menggunakan lembaran kertas koran. Setiap kelompok mendapatkan dua lembar kertas koran. Awal permainan semua anggota kelompok berdiri di atas kertas koran kemudian mereka berpindah dengan cara menggelar kertas koran yang tidak diinjak di depan dan setiap anak berpindah ke kertas koran tersebut. Kemudian kertas koran yang diinjak diambil dan ditaruh di depan kertas koran yang diinjak. Siswa kemudian berpindah. Hal ini dilakukan secara berulang-ulang sampai garis finish.
Berdasarkan hasil pengamatan diperoleh data pretes sebelum siklus pertama dilaksanakan sebanyak $30 \%$ sudah memiliki keterampilan sosial secara baik, 20\% cukup baik, dan $50 \%$ kurang baik.

Permainan pada siklus pertama disebut bermain "Mencegah Kebocoran". Pada permainan ini setiap kelompok diberi satu paralon yang sudah berlubang kecil-kecil. Setiap kelompok diminta untuk mengisi air pada lubang dan menutupnya sehingga tidak terjadi kebocoran. Kelompok yang mampu menahan air di dalam paralon lebih banyak mendapatkan nilai tinggi dibandingkan dengan yang menahan air lebih sedikit. Berdasarkan pengamatan yang dilakukan diperoleh data sebagai tes akhir siklus pertama sebanyak $50 \%$ siswa memiliki keterampilan sosial sangat baik, 20\% cukup dan 30\% kurang baik.

Permainan pada siklus kedua disebut dengan bermain "Membangun rumah." Setiap kelompok diminta untuk menyusun puzzle rumah di papan tulis secara bersamaan. Pada permainan ini 
seorang setiap kelompok seorang siswa maju ke papan tulis yang telah disediakan dan mengambil gambar di kotak serta menempelkan ke papan. Kemudian dilanjutkan oleh siswa kedua dan seterusnya sehingga potongan-potongan puzzle tersebut dapat membentuk sebuah rumah. Berdasarkan hasil pengamatan pada siklus ini diperoleh data sebagai tes akhir siklus kedua menunjukkan $65 \%$ siswa sudah memiliki keterampilan sosial baik, 20\% cukup baik dan $15 \%$ kurang baik.

Pada siklus ketiga disebut dengan bermain "Ganjil-Genap". Pada permainan ini siswa tidak lagi dibagi dalam kelompok kecil tetapi kelompok besar. Aturan permainan ini jika guru mengatakan ganjil maka anak membentuk jumlah yang ganjil bisa tiga, lima, tujuh atau sembilan. Jika anak telah mengelompokkan diri secara ganjil tidak boleh ada penambahan anggota. Siswa lain dapat mencari pasangan untuk membentuk jumlah yang ganjil. Demikian juga untuk jumlah yang genap memiliki aturan permainan yang sama. Pada permainan ini membutuhkan kerjasama, rasa empati, bahasa verbal maupun nonverbal dalam jumlah yang lebih besar. Berdasarkan hasil pengamatan diperoleh data sebagai tes akhir siklus tiga menunjukkan $80 \%$ memiliki keterampilan sosial baik, $15 \%$ cukup baik, dan 5\% kurang baik.

Bermain dan permainan memiliki peran penting pada pertumbuhan dan perkembangan anak. Penggunaan metode ini dapat mengembangkan tidak hanya keterampilan sosial tetapi juga secara fisik dan intelektual. Permainan melibatkan semua kemampuan panca indera secara optimal. Anak dalam bermain selain menggunakan semua anggota tubuh bergerak tetapi juga kepekaan rasa. Kerja sama dalam kelompok baik kecil maupun besar merupakan salah satu cara mengembangkan keterampilan sosial dengan teman sebaya.

Metode bermain juga memberi ruang dan waktu kepada anak untuk bermain secara positif. Bermain selain berfungsi melepaskan kartasis pada anak juga berfungsi untuk mengembangkan daya kreativitas dalam berpikir. Anak melalui permainan dituntut untuk memecahkan masalah secara cepat dan tepat. Untuk dapat mengembangkan permainan yang memiliki makna pada perkembangan sosial anak maka guru perlu mengembangkan permainan sebagai 
metode pembelajaran lebih kreatif. Bentuk-bentuk permainan tradisional dapat pula dijadikan sebagai metode pada pembelajaran. Pemanfaatan permainan tradisional sebagai metode pembelajaran dapat dijadikan sebagai pelestarian budaya.

\section{KESIMPULAN}

Berdasarkan hasil penelitian dapat disimpulkan antata lain sebagai berikut; (1) Metode bermain kelompok dapat meningkatan keterampilan sosial; (2) Metode bermain kelompok efektif digunakan untuk meningkatkan keterampilan sosial; (3) Guru memiliki peran penting dalam memilih dan memilah metode bermain kelompok sehingga sesuai dengan tujuan pembelajaran yang hendak dicapai;

Penggunaan metode bermain kelompok secara variatif memberi dampak pada interaksi yang berbeda pada anak.

Berdasarkan hasil penelitian ini disarankan kepada Pendidikan Anak Usia Dini An-Nisa untuk mengembangkan jenis-jenis permainan sehingga memiliki perbendaharaan metode bermain kelompok lebih banyak lagi.

\section{DAFTAR PUSTAKA}

Amstrong, Thomas, 2002. Sekolah Para Juara, terjemahan Yudhi murtanto, Kaifa, Bandung.

Boeree, C. George, 2000. Sejarah Psikologi: Dari Masa Kelahiran Sampai Masa Modern, terjemahan Abdul Qodir Saleh Ar-ruzz, Media, Jogjakarta.

Erikson, Erik H., 2010. Childhood and Society, terjemahan Helly Prayitno Soetjipto Pustaka Pelajar, Yogyakarta.

Goleman Daniel, 2000. Kecerdasan Emosional, terjemahan Agus T Hermaya, Jakarta, Gramedia.

Kak Seto. 2004. Bermain dan Kreativitas, Jakarta, Papas Sinar Sinanti.

Padmonodewo, Sumiarti. 2003. Pendidikan Anak Prasekolah, Jakarta, Rineka Cipta.

Sarwono, Sarlito Wirawan, 2001. Teori-teori Psikologi Sosial, RajaGrafindo Persada, Jakarta.

Slavin, Robert E., 2010. Psikologi Pendidikan: Teori dan Praktek, terjemahan Marianto Samosir, Jakarta，Index,

Sternberg, Robert J., 2006. CognitivePsycology,Singapore: Thomson Wadsworth.

Monk, Knoers, Siti Rahayu Haditono. 2004,Psikologi Perkembangan, Jogjakarta: Gadjah Mada Unversity Press. 